\title{
BIOCHEMICAL STUDIES OF RAKTAPITTANTAKA LOUHA
}

\section{Research article}

\section{Syed Zaheed Kamal ${ }^{1}$, Md. Mamun Al-Amin ${ }^{2}$}

1. M.S. Student, Department of Pharmacy, Jahangirnagar University, Savar, Dhaka, Bangladesh;

2. Lecturer, Department of Pharmacy, North South University; Plot-15, Block-B, Bashundhara, Dhaka-1229, Bangladesh

\begin{abstract}
Aims: The aim of this study is to investigate the toxicological and pharmacological aspects of the popular ayurvedic preparation Raktapittantaka Louha (RPT) which has been used for hyperacidity, non ulcer dyspepsia and hemorrhagic diseases. Methods: Raktapittantaka Louha was administered orally to male albino rat. After 46 days of treatment period animals were fasted for 18 hours after the last administration. Biochemical studies including; lipid profile, total protein, serum albumin, blood urea nitrogen, bilirubin, creatinine, aspartate aminotransferase, alanine aminotransferase $\&$ alkaline phosphatase were conducted. Results: Triglyceride level was significantly $(\mathrm{p}=0.001)$ lowered in the $R P T$ group than the corresponding control group. Total cholesterols, LDL, VLDL and HDL levels were raised significantly ( $\mathrm{p}=0.05$ ) in the $R P T$ group. The amount of Albumin, Creatinine and Urea in serum were significantly $(\mathrm{p}=0.05)$ increased in $R P T$ group. Lowering of Triglyceride is particularly beneficial in the condition where triglyceride is a burden. Further studies are needed to be conducted to reach a concrete decision about its application in human.
\end{abstract}

Keywords: Raktapittantaka Louha (RPT), Biochemical Study, Toxicology, Pharmacology, Animal study, Cholesterol

\section{Introduction}

A large numbers of modern medicinal agents have been sourcing from the nature in the past (1). Natural plants and their constituents are providing the primary ideas regarding the searching of novel molecule for the treatment of diseases. Traditional and natural medicine including ayurvedic medicine are still remains a popular practice in the subcontinent including India, Sri Lanka and Bangladesh (2, 3). Ayurvedic

*Corresponding Author:

Md. Mamun Al-Amin;

Lecturer, Department of Pharmacy, North South University; Plot-15, Block-B, Bashundhara, Dhaka-1229, Bangladesh

E-mail: bd_pharmacy@yahoo.com

Tel: +880-1927077102 medicines have a wide access to the large number of population in these countries. The acceptance of these medicines increased due to its integrative approach for the prevention and treatment of disease through natural remedies. Traditional people are getting the benefits of this practice from ancient time. But, the uses and the safety profile of all of the ayurvedic medicines are not ensured scientifically $(4,5)$. Moreover, the conflict between traditional medicines and allopathic medicine are needed to be addressed scientifically in the in vivo and in vitro experimental model.

Raktapittantaka Louha (RPT) is a preparation of fruits of Emblica officinalis Gaertn. (traditionally known as amalaki), fruits of Piper longum iron and sugar. Equal mixtures of Emblica officinalis, 
Piper longum and sugar are mixed with the ashes of iron. $R P T$ preparation uses to get relieve from blood bile and sour bile (6). $R P T$ is included (page 303) in the Bangladesh National Formulary of Ayurvedic Medicine 1992 which is Approved by the Government of Bangladesh, Ministry of Health and Family Welfare, Memo No. Health1/Unani-2/89/(Part-1) 116 dated 3-6-1991 (7). Bangladesh National Formulary of Ayurvedic Medicine is compiled by the National Unani and Ayurvedic Formulary Committee and published by the Bangladesh Board of Unani and Ayurvedic Systems of Medicine, 38, Bangabandhu Avenue, Dhaka-1000 under the authority vested in the Board vide section 13(j) of the Bangladesh Unani and Ayurvedic practitioners Ordinance, 1983 in collaboration with the World Health Organization.

Raktapittantaka Louha is used for many therapeutic purpose including hyperacidity, non ulcer dyspepsia [amlapitta], hemorrhagic diseases [raktapitta] and anaemia (8). Composition of $R P T$ is shown in Table 1 . The principle component of RPT is Emblica officinalis [amalaki]. Aqueous extract of Emblica officinalis has an effect on immunity (9), provides hypotensive (10), analgesic (11) and anti-inflammatory (11) actions. E. officinalis possesses antioxidant activity (12), gastro-protective activity (13), cytoprotective, immunomodulating action (14), radiation protective activity (12) and reduces iron overload-induced liver damage (15).

Table1: Plants and ingredients used in the formulation of Raktapittantaka Louha (RPT) (16, 17).

\begin{tabular}{|c|c|c|c|c|}
\hline Name of Plants & Used parts & Botanical Name & Family & Amount \\
\hline Amalaki & Fruit powder & Emblica officinalis & Euphorbiaceae & 1 part \\
\hline Krsna (pippali) & Fruit & Piper longum & Piperaceae & 1 part \\
\hline Lauha (bhasma) & Iron & & & 1 part \\
\hline Sita & & & & 1 part \\
\hline
\end{tabular}

The plant components of $R P T$ have large range of activities. Some of those activities are beneficial and few of them are not in favor of human. Hence, biochemical effect of the $R P T$ preparation is needed to determine. Liver functions might be influenced by $R P T$ components. Reduction of SGOT, SGPT, glutathione-Stransferase levels and DNA synthesis (18), and selective cytotoxicity against tumor and non-tumor cell lines (19) were shown by Emblica officinalis. Another plant component of RPT is Piper longum which is traditionally used for the treatment of intestinal ailments. Iron has been used for treating many diseases including anemia $(20,21)$.

\section{Aim of the study}

Considering the widespread use of Ayurveda as the popular form of traditional medicine in Bangladesh, one cannot emphasize enough the need for establishing the safety profiles of Ayurvedic drugs. Keeping in mind, the present research work on Ayurvedic formulation, Raktapittantaka Louha (RPT) explores a spectrum of its toxicological aspects utilizing experimental animals. We aim to explore the possible toxicological profile of the components of $R P T$ as a whole and in some extent justify the pharmacological uses. The research was carried out in order to characterize the chronic toxicological profile of the marketed Ayurvedic medicinal preparation 
$R P T$ on the following aspects: a) Serum protein/albumin b) Lipid profile c) Liver function test d) Kidney function test e) Serum Uric acid and f) Serum enzymatic activity

\section{Hypothesis}

Previous research studies have been reported many activities of Raktapittantaka Louha (RPT). In our present study we thought that $R P T$ may have a wide range of potential activities. $R P T$ may improve the cholesterol profile; including the lowering of LDL, VLDL, Triglycerides. It may helps to enhance the HDL levels in the blood. It is also thought that $R P T$ can improve the Liver enzymes and may affect the serum protein/albumin, serum enzymes levels in the body.

\section{Materials and Methods}

The Liquid Ayurvedic formulation Raktapittantaka Louha (RPT) was collected from Sri Kundeswari Aushadhalaya Ltd., Chittagong, Bangladesh. The liquid drug RPT was administered per oral route at a dose of 20 $\mathrm{ml} / \mathrm{kg}$ body weight to maintain optimal dosage accuracy without contributing much to the total increase in the body fluid. However, ketamine were administered intra-peritoneally (500 $\mathrm{mg} / \mathrm{kg}$ ). Forty eight-week old albino male rats (Rattus novergicus : Sprague-Dawley strain), bred and maintained at the Animal House of the Department of Pharmacy, Jahangirnagar University, Savar, Dhaka, Bangladesh were used in the toxicological experiment. These animals were apparently healthy and weighed 50-70 g. The animals were housed in a well ventilated hygienic experimental animal house under constant environmental and adequate nutritional conditions throughout the period of the experiment. All of the rats were kept in plastic cages having dimensions of $30 \times 20 \times 13 \mathrm{~cm}$ and soft wood shavings were employed as bedding in the cages. Feeding of animals was done ad libitum, along with drinking water and maintained at natural day night cycle. They were fed with "mouse chow" (prepared according to the formula developed at BCSIR, Dhaka). All experiments on rats were carried out in absolute compliance with the ethical guide for care and use of laboratory animals. Before starting an experiment the animals were carefully marked on different parts of their body, which was later used as identification mark for a particular animal, so that the response of a particular rat prior to and after the administration could be noted separately. A group of equal number of rat as the drug treated group was simultaneously employed in the experiment. They were administered with distilled water as placebo as par the same volume as the drug treated group for the same number of days and this group served as the control. Prior to the experiment, they were randomly divided into 2 groups of 10 animals. Thus ten rats were taken for each group for both control and the experimental group.

\section{Biochemical Experiment}

After acclimatization, administration of the ayurvedic medicinal preparation was done by intra-gastric syringe. Administration of the extract was between the hours of 10 am and noon. At the due of the 46-days treatment period, the animals were fasted for 18 hours and also twenty-four hours after the last administration, the animals were anaesthetized using ketamine $(500 \mathrm{mg} / \mathrm{kg})$. Blood samples were collected from post vena cava and transferred into heparinised tubes immediately. Preparation of Plasma: 
Blood was then centrifuged at 4,000 $\mathrm{g}$ for 10 min using bench top centrifuge (MSE Minor, England) to remove red blood cells and recover plasma. Plasma samples were separated and were collected using dry Pasteur pipette and stored in the refrigerator for analyses. All analyses were completed within $24 \mathrm{~h}$ of sample collection. Determination of Biochemical Parameters: Biochemical analysis was carried out on serum, to assess the state of the liver and kidney. Biochemical studies involved analysis of parameters such as lipid profile, total protein, serum albumin, blood urea nitrogen, bilirubin (total and direct), creatinine, and liver enzymes such as aspartate aminotransferase (AST), alanine aminotransferase (ALT) and alkaline phosphatase (ALP).

Total protein content of the samples was assayed by the Biuret method (22). Serum albumin concentration was determined using the method of Dumas (1997) (23). Triglycerides and total cholesterol concentration as well as protein content were evaluated using assay kits (purchased from Sigma Chemical Co, St Louis, MO, USA). Serum total cholesterol and highdensity lipoprotein cholesterol were determined using Randox Laboratory kit reagents. Serum triacylglycerol level was estimated using Randox Laboratory test kit. Low density lipoprotein (LDL) cholesterol was determined by differential substraction of the sum of the cholesterol fractions from the total cholesterol. The method of Evelyn and Malloy (1938) was employed to determine the serum bilirubin concentration of the samples (24). The procedure of Tietz et al (1994) was used to determine serum creatinine concentration while the serum urea concentration was determined by the method of Kaplan (1965) (25, 26). Alkaline phosphatase activities were determined using the method as described by King and King (1954) (27). The absorbance's of all the tests were determined using spectrophotometer (UV-Visible Spectrophotometer Model No. UV-1601 $\mathrm{PC})$.

\section{Data Analysis}

The group data are expressed as Mean \pm SEM (Standard Error of the Mean). Unpaired " $t$ " tests were conducted for statistical significance tests. SPSS (Statistical Package for Social Science) for WINDOWS (Version 11) was applied for data analysis. Differences between groups were considered significant at $\mathrm{p}=0.05$, 0.01 and 0.001 .

\section{Study, observations and results}

There were no changes $(\mathrm{P}>0.05)$ in the total protein and albumin content in the plasma between control and Raktapittantaka Louha (RPT) group (see table 2). None of the results were significantly different from their corresponding control values. Albumin content in the plasma was increased significantly $(\mathrm{p}=0.05)$ between control and Raktapittantaka Louha (RPT) group. Triglycerides content in the plasma was significantly $(\mathrm{P}=0.05)$ decreased in the $R P T$ rats. On the contrary total cholesterol, LDL, VLDL and HDL content in the plasma were surprisingly increased $(\mathrm{P}=0.05)$. Bilirubin content in the plasma was remaining unchanged. Creatinine and Urea content in the plasma were significantly $(\mathrm{P}=0.05)$ increased in the $R P T$ group of rats from their corresponding control values. Enzyme activity analysis showed that SGPT, sGOT and ALP levels were remain unchanged in both $R P T$ and control group of rats. 
Table 2: Biochemical parameters of control and Raktapittantaka Louha (RPT) rats. Albumin level was increased. Triglycerides (TG), Very high density lipoprotein (VLDL), Low density lipoprotein (LDL) and High density lipoprotein (HDL) levels were increased. Serum Creatinine and urea levels were increased. Serum glutamic pyruvate transaminase (sGPT), serum glutamic oxaloacetic transaminase (sGOT), alkaline phosphatase (ALP) were remain unchanged.

\begin{tabular}{|c|c|c|c|c|c|c|}
\hline & \multicolumn{3}{|c|}{ Male } & \multicolumn{3}{|c|}{ Female } \\
\hline & $\begin{array}{l}\text { Control } \\
(n=10)\end{array}$ & $\begin{array}{l}R P T \\
(n=10)\end{array}$ & P Value & $\begin{array}{l}\text { Control } \\
(\mathrm{n}=10)\end{array}$ & $\begin{array}{l}R P T \\
(\mathrm{n}=10)\end{array}$ & P Value \\
\hline Total protein & $\begin{array}{l}5629.09 \pm \\
65.89\end{array}$ & $\begin{array}{l}5976.22 \pm \\
93.94\end{array}$ & $0.048^{*}$ & $\begin{array}{l}5384.66 \pm \\
60.43\end{array}$ & $\begin{array}{l}5828.99 \pm \\
73.42\end{array}$ & 0.058 \\
\hline Albumin & $\begin{array}{l}4517.12 \pm \\
117.60\end{array}$ & $\begin{array}{l}5119.13 \pm \\
83.67\end{array}$ & $0.001 * * *$ & $\begin{array}{l}4221.30 \pm \\
75.56\end{array}$ & $\begin{array}{l}4724.83 \pm \\
92.28\end{array}$ & $0.003 * *$ \\
\hline Triglycerides & $\begin{array}{l}96.47 \pm \\
1.11\end{array}$ & $\begin{array}{l}86.72 \pm \\
1.95\end{array}$ & $0.001 * * *$ & $\begin{array}{l}97.96 \pm \\
3.59\end{array}$ & $\begin{array}{l}80.52 \pm \\
2.22\end{array}$ & $0.001 * * *$ \\
\hline $\begin{array}{l}\text { Total } \\
\text { Cholesterol }\end{array}$ & $\begin{array}{l}68.18 \pm \\
1.69\end{array}$ & $\begin{array}{l}78.98 \pm \\
1.58\end{array}$ & $0.001 * * *$ & $\begin{array}{l}75.24 \pm \\
1.64\end{array}$ & $\begin{array}{l}85.80 \pm \\
1.63\end{array}$ & $0.008 * *$ \\
\hline VLDL & $\begin{array}{l}14.75 \pm \\
0.76\end{array}$ & $\begin{array}{l}18.89 \pm \\
0.58\end{array}$ & $0.001 * * *$ & $\begin{array}{l}17.74 \pm \\
0.43\end{array}$ & $\begin{array}{l}20.48 \pm \\
0.59\end{array}$ & $0.001 * * *$ \\
\hline LDL & $\begin{array}{l}19.1 \pm \\
0.77\end{array}$ & $\begin{array}{l}23.97 \pm \\
0.82\end{array}$ & $0.001 * * *$ & $\begin{array}{l}19.65 \pm \\
0.69\end{array}$ & $\begin{array}{l}23.02 \pm \\
0.77\end{array}$ & $0.038^{*}$ \\
\hline HDL & $\begin{array}{l}33.01 \pm \\
0.88\end{array}$ & $\begin{array}{l}39.85 \pm \\
1.09\end{array}$ & $0.001 * * *$ & $\begin{array}{l}34.37 \pm \\
1.01\end{array}$ & $\begin{array}{l}39.59 \pm \\
0.99\end{array}$ & $0.041 *$ \\
\hline Bilirubin & $\begin{array}{l}0.12 \pm \\
0.002\end{array}$ & $\begin{array}{l}0.13 \pm \\
0.002\end{array}$ & 0.729 & $\begin{array}{l}0.07 \pm \\
0.004\end{array}$ & $\begin{array}{l}0.11 \pm \\
0.004\end{array}$ & 0.792 \\
\hline Creatinine & $\begin{array}{l}0.94 \pm \\
0.012\end{array}$ & $\begin{array}{l}1.03 \pm \\
0.02\end{array}$ & $0.041^{*}$ & $\begin{array}{l}0.97 \pm \\
0.04\end{array}$ & $\begin{array}{l}1.16 \pm \\
0.039\end{array}$ & $0.036^{*}$ \\
\hline Urea & $\begin{array}{l}65.86 \pm \\
1.04\end{array}$ & $\begin{array}{l}70.30 \pm \\
0.89\end{array}$ & $0.048^{*}$ & $\begin{array}{l}57.53 \pm \\
1.24\end{array}$ & $\begin{array}{l}64.20 \pm \\
1.05\end{array}$ & $0.013^{*}$ \\
\hline Uric acid & $\begin{array}{l}2.57 \pm \\
0.05\end{array}$ & $\begin{array}{l}2.97 \pm \\
0.09\end{array}$ & $0.009^{*}$ & $\begin{array}{l}2.79 \pm \\
0.09\end{array}$ & $\begin{array}{l}3.22 \pm \\
0.08\end{array}$ & $0.012^{*}$ \\
\hline sGPT & $\begin{array}{l}60.27 \pm \\
0.12\end{array}$ & $\begin{array}{l}60.81 \pm \\
0.17\end{array}$ & 0.836 & $\begin{array}{l}50.16 \pm \\
0.14\end{array}$ & $\begin{array}{l}50.69 \pm \\
0.14\end{array}$ & 0.904 \\
\hline sGOT & $\begin{array}{l}101.73 \pm \\
0.30\end{array}$ & $\begin{array}{l}102.83 \pm \\
0.30\end{array}$ & 0.801 & $\begin{array}{l}82.50 \pm \\
0.20\end{array}$ & $\begin{array}{l}833.35 \pm \\
0.27\end{array}$ & 0.866 \\
\hline ALP & $\begin{array}{l}43.56 \pm \\
0.10\end{array}$ & $\begin{array}{l}43.06 \pm \\
0.17\end{array}$ & 0.797 & $\begin{array}{l}35.45 \pm \\
0.10\end{array}$ & $\begin{array}{l}34.91 \pm \\
0.019\end{array}$ & 0.802 \\
\hline
\end{tabular}

Note: ${ }^{*} \mathrm{p}<0.05, * * \mathrm{p}<0.01, * * * \mathrm{p}<0.001$

\section{Discussion}

In the present study toxicological and pharmacological profile of Raktapittantaka Louha (RPT) was investigated in the animal model. Experimental results demonstrated no changes of total protein content in the blood plasma. This result indicates no effect of $R P T$ preparation on the protein level in animal. An increased level of albumin was found in the RPT animal group which indicates that the component of RPT can affect the albumin level. The component of RPT Emblica officinalis has 
albumin improving properties. Previous findings (28) also support our present result.

Result of the present study demonstrated that only the triglyceride level was reduced after administration of $R P T$. RPT component/(s) might affect the reduction of triglyceride in the plasma. $R P T$ components might have this property due to the presence of saponins and phytosterols. It is noted that Emblica officinalis was proven to have triglyceride lowering activity in previous research paper done by Nain et al., in 2012 (29, 30). Moreover, Piper longum was proved to have antihyperlipidemic compounds by Jin et al., in 2009 (31). Other lipid components of the blood such as LDL, VLDL even HDL were enhanced after $R P T$ administration.

Our result shows the increased level of Creatinine and Urea after the administration of $R P T$ preparation. Completely opposite finding (decreased level of creatinine and urea) was reported by Nain et al., in 2012 after the administration of Emblica officinalis in the streptozotocin-induced type-2 diabetes mellitus (T2DM) rats (29) and no change was observed by Chen et al., in 2009 (32).

\section{Conclusions}

In this study toxicological and pharmacological aspects of Raktapittantaka Louha (RPT) was investigated. Raktapittantaka Louha possesses a wide range of pharmacological activities. Triglyceride lowering action was found which is particularly beneficial. Ayurvedic preparation generally consists of multiple plants and varieties of chemical constituents in their different parts as well. Further studies should be conducted to explore the chemical constituent/(s) responsible to exhibit the pharmacological and toxicological profiles of $R P T$ preparation. We only suggest that $R P T$ preparation may be prescribed under careful monitoring by the registered physicians.

\section{References}

1. Cragg G.M, Newman D.J, Natural product drug discovery in the next millennium. Pharmaceutical biology. 2001; 39; Suppl 1:8-17

2. Chopra A, Doiphode V.V, Ayurvedic medicine. Core concept, therapeutic principles, and current relevance. The Medical clinics of North America. 2002; 86(1); 75-89

3. Urmila T, Supriya B, Pharmacovigilance of ayurvedic medicines in India. Indi. J. of Pharmacology. February 2008;40(7); 10-2

4. Gogtay N.J, Bhatt H.A, Dalvi S.S, Kshirsagar N.A, The use and safety of non-allopathic Indian medicines. Drug safety: an international journal of medical toxicology and drug experience. 2002; 25(14); 1005-19

5. Thatte U.M, Rege N.N, Phatak S.D, Dahanukar S.A. The flip side of Ayurveda. Journal of postgraduate medicine. 1993; 39(4):179-82, 82a-82b

6. Nugroho A, Siswanto E, Lukitaningsih E, Andrie M, Warditiani N, Pramono $\mathrm{S}$. Antidiabetic and antihiperlipidemic effect of Andrographis paniculata (Burm. f.) Nees and andrographolide in high-fructose-fat-fed rats, May-2012; 377-81

7. Anonymous. Bangladesh National Formulary of Ayurvedic Medicine 1992 Dhaka

8. Arogyadhamc H.C, Ayurvedic Yog khadirarista. Opp. Govt School, G.T. Road, Near Honey Garden Banquet Hall, Ayurveda Dham Road, Gharaunda (Karnal) - 132114, Haryana, INDIA, available from: http://www.ayurvedaconsultants.com, accessed on 28 February 2013

9. Ismail S, Asad M. Immunomodulatory activity of Acacia catechu. Indian 
journal of physiology and pharmacology. 2009; 53(1); 25-33

10. Sham J.S.K, Chiu K.W, Pang P.K.T, Hypotensive Action of Acacia catechu. Planta medica. 1984; 50(02); 177-80

11. Yimam M, Brownell L, Hodges M, Jia Q. Analgesic Effects of a Standardized Bioflavonoid Composition from Scutellaria baicalensis and Acacia catechu. Journal of Dietary Supplements. 2012; 9(3); 155-65

12. Scartezzini P, Speroni E, Review on some plants of Indian traditional medicine with antioxidant activity. J Ethnopharmacol. 2000; 71(1-2); 23-43

13. Al-Rehaily A.J, Al-Howiriny T.A, AlSohaibani M.O, Rafatullah S. Gastroprotective effects of 'Amla' Emblica officinalis on in vivo test models in rats. Phytomedicine. 2002; 9(6); 515-22

14. Sairam K, Rao C.V, Babu M.D, Kumar K.V, Agrawal V.K, Antiulcerogenic effect of methanolic extract of Emblica officinalis: an experimental study. J Ethnopharmacol. 2002; 82(1); 1-9

15. Nayak B.S, Suresh R, Rao A.V, Pillai G.K, Davis E.M, Ramkissoon V, Evaluation of wound healing activity of Vanda roxburghii: a preclinical study in a rat model. The Intl. J. of lower extremity wounds. 2005; 4(4); 200-4

16. Abraham E, Ayurvedic medicinal plants. Kerala, India 2013, accessed on 26 February 2013; available from: http://ayurvedicmedicinalplants.com

17. Logayurveda, Ayurveda Formulation, 2013, accessed on 26 February 2013; available from: www.logayurveda.com

18. Sultana S, Ahmad S, Khan N, Jahangir T. Effect of Emblica officinalis Gaertn. on $\mathrm{CCl} 4$ induced hepatic toxicity and DNA synthesis in Wistar rats. Indian journal of experimental biology. 2005; 43(5); 430-6

19. Qi W.Y, Li Y, Hua L, Wang K, Gao K. Cytotoxicity and structure activity relationships of phytosterol from
Phyllanthus emblica. Fitoterapia. 2013; $84 ; 252-6$

20. Saravanan M, Pandikumar P, Prakash Babu N, Ignacimuthu S. Antihyperlipidemic activity of Ichnocarpus frutescens in triton WR1339-induced and high-fat diet animals. Pharm Biol. 2011; 49(10); 1074-81

21. Singh P, Srivastava M.M, Khemani L.D, Renoprotective effects of Andrographis paniculata (Burm. f.) Nees in rats. Upsala J. of Med. Sci. 2009; 114(3); 136-9

22. Wright P.J, Plummer D.T, The use of urinary enzyme measurements to detect renal damage caused by nephrotoxic compounds. Biochem. pharmacol. 1974; 23(1); 65-73

23. Dumas B.T, Watson W.A, Biggs H.G, Albumin standards and the measurement of serum albumin with bromcresol green. Clinica chimica acta; 1997; 258(1); 21-30

24. Evelyn KA, Malloy HT. Microdetermination of oxyhemoglobin, methemoglobin and sulfhemoglobin in a single sample of blood. J. of Biol. Chem. 1938; 126(2); 655-62

25. NW T, EL P, O S-A. Tietz textbook of Clinical Chemistry. 1eds. BCaAE, editor: WB Saunders Company London; 1994

26. MM. K. Standard Method of Clinical Chemistry. Meites, editor: Academic Press Inc., New York; 1965

27. Kind P.R, King E.J, Estimation of plasma phosphatase by determination of hydrolysed phenol with aminoantipyrine. J. of clinical pathology. 1954; 7(4); 322-6

28. Rao T.P, Sakaguchi N, Juneja L.R, Wada E, Yokozawa T. Amla (Emblica officinalis Gaertn.) extracts reduce oxidative stress in streptozotocininduced diabetic rats. J. of medicinal food. $2005 ; 8(3) ; 362-8$ 
29. Nain P, Saini V, Sharma S, Nain J. Antidiabetic and antioxidant potential of Emblica officinalis Gaertn. leaves extract in streptozotocin-induced type2 diabetes mellitus (T2DM) rats. $\mathrm{J}$ Ethnopharmacol. 2012; 142(1); 65-71

30. Koshy S.M, Bobby Z, Hariharan A.P, Gopalakrishna S.M, Amla (Emblica officinalis) extract is effective in preventing high fructose diet-induced insulin resistance and atherogenic dyslipidemic profile in ovariectomized female albino rats. Menopause (New York, NY). 2012; 19(10); 1146-55

31. Jin Z, Borjihan G, Zhao R, Sun Z, Hammond G.B, Uryu T. Antihyperlipidemic compounds from the fruit of Piper longum L. Phytotherapy research: 2009; 23(8); 1194-6

32. Chen T.S, Liou S.Y, Chang Y.L, Supplementation of Emblica officinalis (Amla) extract reduces oxidative stress in uremic patients. Am J Chin Med. 2009; $\quad 37(1)$

$19-25$ 